\title{
Thermodynamics of TiN Formation in Fe-Cr Melts
}

\author{
Jong-Jin PAK, Yong-Soo JEONG, ${ }^{1)}$ In-Kook HONG, ${ }^{2)}$ Woo-Yeol CHA, ${ }^{3)}$ Dong-Sik KIM ${ }^{4)}$ and Yun-Yong LEE ${ }^{4)}$ \\ Division of Materials and Chemical Engineering, Hanyang University, Ansan 426-791, Korea. E-mail: jjpark@hanyang.ac.kr \\ 1) Formerly Graduate Student, Division of Materials and Chemical Engineering, Hanyang University, Ansan 426-791, Korea. \\ Now at Changwon Specialty Steel Co., Ltd., Changwon, 641-370, Korea. \\ 2) Formerly Graduate Student, Division of Materials and Chemical Engineering, Hanyang University, Ansan 426-791, Korea. \\ Now at Power Generation Division, Dong-Hae Thermal Power Plant, Korea East-West Power Co., Ltd., Donghae 240-230, \\ Korea. $\quad 3)$ Formerly Graduate Student, Division of Materials and Chemical Engineering, Hanyang University, Ansan \\ 426-791, Korea. Now at Department of Metallurgy, Graduate School of Engineering, Tohoku University, Aoba-yama, Sendai \\ 980-8579 Japan. $\quad$ 4) Stainless Steel Research Group, Technical Research Laboratories, POSCO, Pohang 790-785, Korea.
}

( Received on March 14, 2005; accepted on May 25, 2005)

\begin{abstract}
The equilibrium solubility of titanium and nitrogen in $\mathrm{Fe}-\mathrm{Cr}$ melts was measured in the presence of pure solid TiN under various nitrogen pressures. The activity coefficients of titanium and nitrogen relative to 1 mass \% standard state in liquid iron were calculated from the experimental results in the temperature range of 1843-1923 K. The first and second order interaction parameters of chromium on titanium and nitrogen were determined as a function of temperature. The validity of thermodynamic parameters determined in the present study was examined by constructing the stability diagram of TiN for Fe-Cr melts and by observing the formation of primary and secondary TiN inclusions at controlled titanium and nitrogen contents in the melt.
\end{abstract}

KEY WORDS: thermodynamics; TiN; chromium; titanium; nitrogen; interaction parameters; inclusion.

\section{Introduction}

In stainless steelmaking processes, a strong nitride-forming element such as titanium is often added to stabilize nitrogen and improve mechanical properties of steel via the grain refinement during hot rolling. Recently, the formation of titanium nitride as a secondary inclusion precipitated during solidification is of great interest because it is known to help the formation of equi-axed cast structure. ${ }^{1)}$ On the other hand, titanium nitride formed in liquid steel can agglomerate and cause a nozzle clogging problem during continuous casting, and surface defects in final products.

In spite of the importance of inclusion control in Ti-bearing stainless steels, the thermodynamic data of titanium in $\mathrm{Fe}-\mathrm{Cr}$ melts are not consistent in the literature, ${ }^{2-5)}$ and little information is available at temperatures other than $1873 \mathrm{~K}$. Therefore, the purpose of this study is to obtain reliable thermodynamic data of titanium and nitrogen in $\mathrm{Fe}-\mathrm{Cr}$ melts as a function of temperature, in order to predict under what condition titanium nitride will form during stainless steel processing.

\section{Experimental Procedures}

The metal-nitride-gas equilibration experiments were carried out to determine soluble titanium and nitrogen in $\mathrm{Fe}-\mathrm{Cr}$ melts in the presence of pure solid TiN under various nitrogen pressures. The experiment was carried out in a graphite resistance furnace in the temperature range of $1843-1923 \mathrm{~K}$. A detailed description of the experimental system is given in the previous article. ${ }^{6}$

Master alloys of $\mathrm{Fe}-30$ mass $\% \mathrm{Cr}$ and $\mathrm{Fe}-4$ mass\% $\%$ Ti were made by melting high purity iron ( 99.99 mass\% purity) and adding chromium (99.9 mass\% purity) and titanium (99.5 mass\% purity) in a fused magnesia crucible in an $\mathrm{Ar}-3 \% \mathrm{H}_{2}$ atmosphere using an induction furnace. Desired portions of master alloys were charged to make an intermediate melt composition for each experiment. Fifteen grams of alloy and $1 \mathrm{~g}$ of titanium nitride pellets were placed in a high purity alumina crucible (OD: $2.2 \mathrm{~cm}$, ID: $1.8 \mathrm{~cm}, \mathrm{H}$ : $2.5 \mathrm{~cm}$ ). A detailed description of the experimental procedure is given in the previous article. $\left.{ }^{6}\right)$ It was found that the time required for the metal-nitride-gas equilibrium was longer than $80 \mathrm{~h}$. Therefore, for each set of experiment, the alloy melts with different initial titanium contents $(0$ and $0.2 \mathrm{mass} \% \mathrm{Ti}$ ) were equilibrated, and hence the equilibrium could be approached from high and low titanium contents with respect to the equilibrium values. After each experiment, the metal samples were quenched and analyzed for $\mathrm{Cr}$ and $\mathrm{Ti}$ by the ICP-AES, and $\mathrm{N}$ and $\mathrm{O}$ by the inert gas fusion-infrared absorptiometry.

\section{Results and Discussion}

\subsection{Activity Coefficient of Titanium}

Table 1 summarizes the experimental results of metal-nitride-gas equilibration for $\mathrm{Fe}-\mathrm{Cr}$ melts at $1843-1923 \mathrm{~K}$. During the equilibration experiments, the following equilibrium can be established: 
Table 1. Experimental results of metal-nitride-gas equilibration in $\mathrm{Fe}-\mathrm{Cr}$ melts.

\begin{tabular}{|c|c|c|c|c|c|c|}
\hline $\begin{array}{c}\text { Temp. } \\
\left({ }^{\circ} \mathbf{K}\right)\end{array}$ & $\begin{array}{l}P_{\mathrm{N}_{2}} \\
\text { (atm) }\end{array}$ & {$[\% \mathrm{Cr}]$} & [\%Ti] & {$[\% \mathrm{~N}]$} & {$[\% 0]$} & $\begin{array}{c}\text { Reaction } \\
\text { Type }\end{array}$ \\
\hline \multirow{3}{*}{1843} & \multirow{3}{*}{0.1} & 8.13 & 0.0584 & 0.0381 & 0.0043 & $\bar{\uparrow}$ \\
\hline & & 8.34 & 0.0571 & 0.0407 & 0.0016 & $\downarrow$ \\
\hline & & 16.02 & 0.0371 & 0.0921 & 0.0035 & $\uparrow$ \\
\hline \multirow{11}{*}{1873} & \multirow{6}{*}{0.1} & 7.08 & 0.0940 & 0.0347 & 0.0026 & $\uparrow$ \\
\hline & & 7.26 & 0.0960 & 0.0333 & 0.0054 & $\downarrow$ \\
\hline & & 10.28 & 0.0839 & 0.0522 & 0.0030 & $\uparrow$ \\
\hline & & 15.16 & 0.0658 & 0.0957 & 0.0028 & $\downarrow$ \\
\hline & & 15.72 & 0.0890 & 0.0758 & 0.0048 & $\uparrow$ \\
\hline & & 15.89 & 0.0710 & 0.0859 & 0.0045 & $\uparrow$ \\
\hline & \multirow{4}{*}{0.3} & 7.59 & 0.0760 & 0.0624 & 0.0031 & $\uparrow$ \\
\hline & & 7.29 & 0.0707 & 0.0652 & 0.0034 & $\downarrow$ \\
\hline & & 14.65 & 0.0610 & 0.1293 & 0.0104 & $\uparrow$ \\
\hline & & 15.18 & 0.0562 & 0.1252 & 0.0071 & $\downarrow$ \\
\hline & 0.5 & 8.31 & 0.0507 & 0.0836 & 0.0052 & $\uparrow$ \\
\hline \multirow{9}{*}{1923} & \multirow{4}{*}{0.3} & 7.43 & 0.1300 & 0.0644 & 0.0069 & $\downarrow$ \\
\hline & & 7.50 & 0.1120 & 0.0680 & 0.0089 & $\uparrow$ \\
\hline & & 14.97 & 0.1220 & 0.1223 & 0.0119 & $\uparrow$ \\
\hline & & 16.16 & 0.1230 & 0.1175 & 0.0142 & $\downarrow$ \\
\hline & \multirow{3}{*}{0.5} & 7.70 & 0.1090 & 0.0755 & 0.0057 & $\downarrow$ \\
\hline & & 7.80 & 0.0839 & 0.0772 & 0.0054 & $\uparrow$ \\
\hline & & 15.79 & 0.0907 & 0.1364 & 0.0097 & $\downarrow$ \\
\hline & \multirow{2}{*}{1} & 11.00 & 0.0837 & 0.1507 & 0.0019 & $\downarrow$ \\
\hline & & 14.48 & 0.1010 & 0.2026 & 0.0046 & $\downarrow$ \\
\hline
\end{tabular}

$* \uparrow: \operatorname{TiN}(\mathrm{s}) \rightarrow \underline{\mathrm{Ti}}+1 / 2 \mathrm{~N}_{2}(\mathrm{~g}), \quad \downarrow: \operatorname{Ti}+1 / 2 \mathbf{N}_{2}(\mathrm{~g}) \rightarrow \operatorname{TiN}(\mathrm{s})$

$$
\begin{gathered}
\operatorname{TiN}(\mathrm{s})=\underline{\mathrm{Ti}}+\frac{1}{2} \mathrm{~N}_{2}(\mathrm{~g}) \cdots \cdots \cdot . \cdot . \\
\Delta G_{1}^{\circ}=375402-172.89 T \quad \mathrm{~J}^{7,8)} \\
K_{1}=\frac{h_{\mathrm{Ti}} P_{\mathrm{N}_{2}}^{1 / 2}}{a_{\mathrm{TiN}}}=f_{\mathrm{Ti}}[\% \mathrm{Ti}] P_{\mathrm{N}_{2}}^{1 / 2}
\end{gathered}
$$

where $K_{1}$ is the equilibrium constant for Reaction (1), and $f_{\mathrm{Ti}}$ is the activity of titanium relative to 1 mass $\%$ standard state in liquid iron and $f_{\mathrm{Ti}}$ is the activity coefficient of titanium. $P_{\mathrm{N}_{2}}$ is the nitrogen partial pressure in the gas phase. Under the present experimental condition, the activity of titanium nitride is unity

The equilibrium constant $K_{1}$ can be rewritten as the following relation using the appropriate interaction parameters:

$$
\begin{aligned}
\log K_{1}= & \log f_{\mathrm{Ti}}+\log [\% \mathrm{Ti}]+\frac{1}{2} \log P_{\mathrm{N}_{2}} \\
= & e_{\mathrm{Ti}}^{\mathrm{Cr}}[\% \mathrm{Cr}]+r_{\mathrm{Ti}}^{\mathrm{Cr}}[\% \mathrm{Cr}]^{2}+e_{\mathrm{Ti}}^{\mathrm{Ti}}[\% \mathrm{Ti}]+e_{\mathrm{Ti}}^{\mathrm{N}}[\% \mathrm{~N}] \\
& +e_{\mathrm{Ti}}^{\mathrm{O}}[\% \mathrm{O}]+\log [\% \mathrm{Ti}]+\frac{1}{2} \log P_{\mathrm{N}_{2}} \ldots \ldots \ldots \ldots \ldots . . .
\end{aligned}
$$

Then

$$
\begin{aligned}
& \log f_{\mathrm{Ti}}^{\mathrm{Cr}}=e_{\mathrm{Ti}}^{\mathrm{Cr}}[\% \mathrm{Cr}]+r_{\mathrm{Ti}}^{\mathrm{Cr}}[\% \mathrm{Cr}]^{2} \\
& =\log K_{1}-e_{\mathrm{Ti}}^{\mathrm{Ti}}[\% \mathrm{Ti}]-e_{\mathrm{Ti}}^{\mathrm{N}}[\% \mathrm{~N}]-e_{\mathrm{Ti}}^{\mathrm{O}}[\% \mathrm{O}] \\
& \quad-\log [\% \mathrm{Ti}]-\frac{1}{2} \log P_{\mathrm{N}_{2}} \ldots \ldots \ldots \ldots \ldots \ldots \ldots \ldots \ldots \ldots \ldots \ldots \ldots \ldots
\end{aligned}
$$

where $f_{\mathrm{Ti}}^{\mathrm{Cr}}$ is the interaction coefficient of $\mathrm{Cr}$ on $\mathrm{Ti}$ in liquid iron, and $e_{\mathrm{Ti}}^{\mathrm{Cr}}$ and $r_{\mathrm{Ti}}^{\mathrm{Cr}}$ are the first and second order interaction parameters of $\mathrm{Cr}$ on $\mathrm{Ti}$, respectively. In the present experiment, aluminum content in metal samples in alumina crucibles after the equilibration was less than $50 \mathrm{ppm}$. Therefore, the effect of $\mathrm{Al}$ on Ti activity was assumed to be negligible.

The values of $e_{\mathrm{Ti}}^{\mathrm{Cr}}$ and $r_{\mathrm{Ti}}^{\mathrm{Cr}}$ in Eq. (3) can be determined from the experimental results of equilibrium titanium and nitrogen contents as a function of chromium content in $\mathrm{Fe}-\mathrm{Cr}-\mathrm{Ti}-\mathrm{N}$ melts. The effect of oxygen content in the melt on the activity coefficient of titanium was also considered. The $e_{\mathrm{Ti}}^{\mathrm{Ti}}, e_{\mathrm{Ti}}^{\mathrm{N}}$ and $e_{\mathrm{Ti}}^{\mathrm{O}}$ values used for the calculation are listed in Table 2. ${ }^{2,7,9)}$ In Fig. 1, the values of $\log f_{\mathrm{Ti}}^{\mathrm{Cr}}$ are plotted vs. percent chromium in the alloys using the relation expressed by Eq. (3). The effect of oxygen content in the melt on the $f_{\mathrm{Ti}}^{\mathrm{Cr}}$ value was not significant at the oxygen level ob- 
Table 2. Interaction parameters used in the present study.

\begin{tabular}{|c|c|c|c|}
\hline & $\mathbf{1 8 7 3 K}$ & Temp. Dependency & References \\
\hline$e_{T i}^{T_{i}}$ & 0.048 & - & $(9)$ \\
\hline$e_{T_{i}}^{N}$ & -2.041 & $-19,500 / \mathrm{T}+8.37$ & $(7)$ \\
\hline$e_{T i}^{O}$ & -1.8 & - & $(2)$ \\
\hline$e_{T_{i}}^{S i}$ & -0.0256 & $177.5 / \mathrm{T}-0.12$ & $(6)$ \\
\hline$e_{N}^{T_{i}}$ & -0.593 & $-5,700 / \mathrm{T}+2.45$ & $(7)$ \\
\hline$e_{N}^{N}$ & 0 & - & $(12)$ \\
\hline$e_{N}^{O}$ & 0.05 & - & $(2)$ \\
\hline$e_{N}^{S i}$ & 0.0491 & $-286.2 / \mathrm{T}+0.202$ & $(6)$ \\
\hline
\end{tabular}

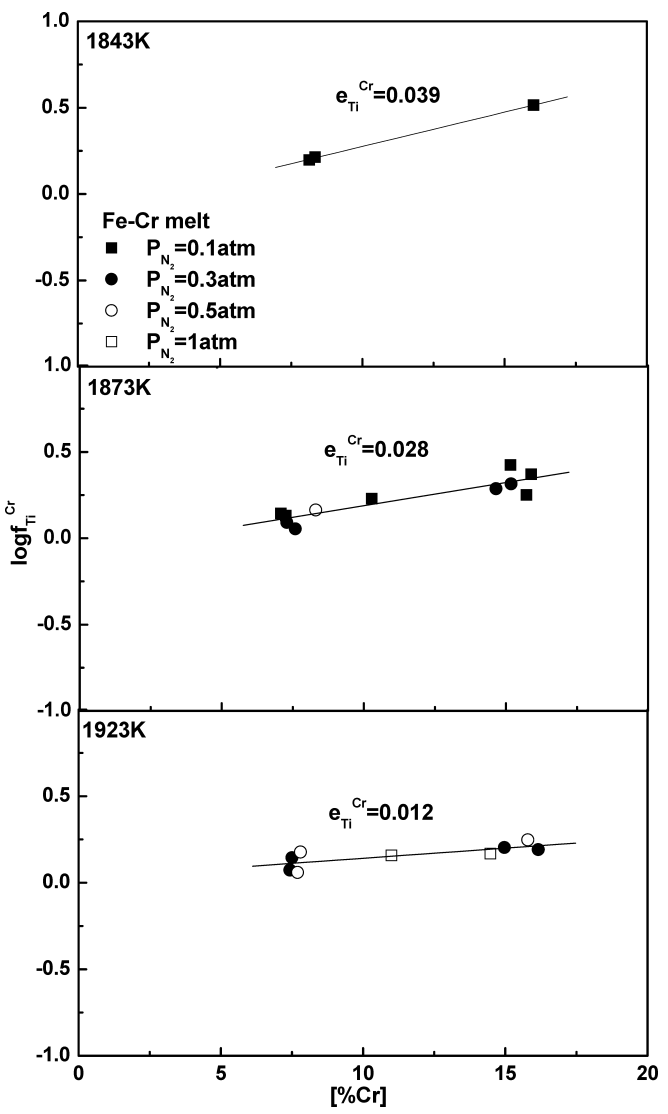

Fig. 1. Relations between $\log f_{\mathrm{Ti}}^{\mathrm{Cr}}$ and $[\% \mathrm{Cr}]$ in $\mathrm{Fe}-\mathrm{Cr}-\mathrm{Ti}-\mathrm{N}$ melts.

tained in the present study. The data determined at different nitrogen partial pressures and temperatures show good linear relationships up to 16 mass $\%$ of chromium content. The relationship can be analytically expressed using only the first order interaction parameter, $e_{\mathrm{Ti}}^{\mathrm{Cr}}$ and it can be determined as 0.028 at $1873 \mathrm{~K}$ by a linear regression analysis of data. The $e_{\mathrm{Ti}}^{\mathrm{Cr}}$ values at other temperatures are also shown in Fig. 1. The temperature dependence of $e_{\mathrm{Ti}}^{\mathrm{Cr}}$ value can be expressed as 1 196/T-0.61 from the plot shown in Fig. 2. The interaction parameters determined in the present study are compared with previous results ${ }^{2-5)}$ in Table 3.

The first order interaction parameter, $e_{\mathrm{Ti}}^{\mathrm{Cr}}$ was compiled as 0.055 at $1873 \mathrm{~K}$ by Sigworth and Elliott, ${ }^{2)}$ however, it has been claimed to be the value for the $\mathrm{Ni}-\mathrm{Cr}-\mathrm{Ti}$ system. ${ }^{10}$ ) Wada et $a l .{ }^{3)}$ determined the first and second order parame-

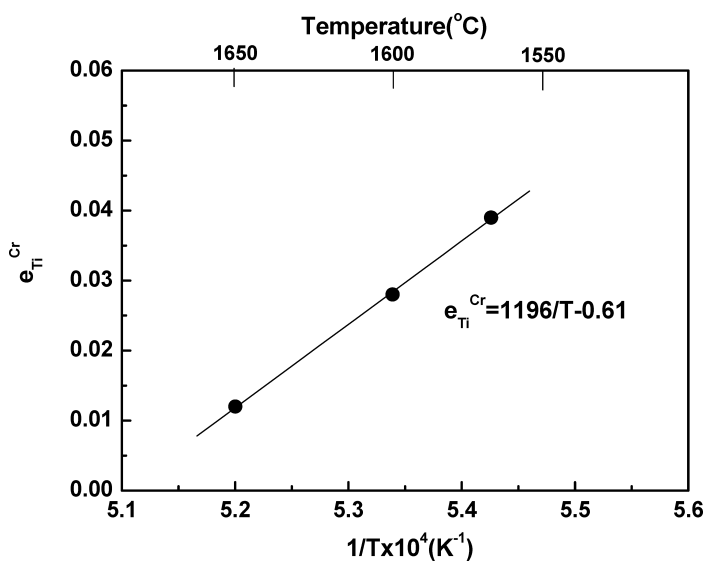

Fig. 2. Temperature dependence of $e_{\mathrm{Ti}}^{\mathrm{Cr}}$ in molten Fe.

Table 3. Interaction parameters of $\mathrm{Cr}$ on $\mathrm{Ti}$ and $\mathrm{N}$.

\begin{tabular}{|c|c|c|c|}
\hline & $1873 K$ & Temp. Dependency & References \\
\hline \multirow{5}{*}{$e_{T i}^{C r}$} & 0.028 & $1196 / \mathrm{T}-0.61$ & present study \\
\hline & 0.055 & - & (2) \\
\hline & 0.022 & - & (3) \\
\hline & 0.016 & - & (4) \\
\hline & 0.024 & - & (5) \\
\hline \multirow{3}{*}{$r_{T i}^{C r}$} & 0 & - & present study \\
\hline & -0.0001 & - & (3) \\
\hline & 0.0005 & - & (4) \\
\hline \multirow{4}{*}{$e_{N}^{C r}$} & -0.045 & $-850 / T+0.409$ & present study \\
\hline & -0.047 & - & (2) \\
\hline & -0.046 & $-164 / \mathrm{T}+0.0415$ & (3) \\
\hline & -0.045 & - & (13) \\
\hline \multirow{3}{*}{$r_{N}^{C r}$} & 0 & - & present study \\
\hline & -0.0004 & - & (2) \\
\hline & 0.00032 & $1.67 / \mathrm{T}-0.0006$ & (3) \\
\hline
\end{tabular}

ters, $e_{\mathrm{Ti}}^{\mathrm{Cr}}$ and $r_{\mathrm{Ti}}^{\mathrm{Cr}}$ in $\mathrm{Fe}-\mathrm{Cr}-\mathrm{Ti}-\mathrm{N}$ system (up to 30 mass $\% \mathrm{Cr}$ ) as 0.022 and -0.0001 , respectively, at $1873 \mathrm{~K}$ by the multiple regression analysis of data from their titanium nitride precipitation experiments using the Sieverts' method. Yuanchang et al. ${ }^{4)}$ used a silver bath iso-activity method, and determined values of $\varepsilon_{\mathrm{Ti}}^{\mathrm{Cr}}$ and $\rho_{\mathrm{Ti}}^{\mathrm{Cr}}$ in $\mathrm{Fe}-\mathrm{Cr}-\mathrm{Ti}-\mathrm{C}$ system as 3.46 and 10.43 , respectively, at $1873 \mathrm{~K}$ for chromium contents up to $X_{\mathrm{Cr}}=0.0458$ (equivalent to $4.5 \mathrm{mass} \% \mathrm{Cr}$ ). Using the relations regarding the transformation of the interaction parameters by Lupis and Elliott, ${ }^{11)}$ the values of $e_{\mathrm{Ti}}^{\mathrm{Cr}}$ and $r_{\mathrm{Ti}}^{\mathrm{Cr}}$ can be determined as 0.016 and 0.0005 , respectively.

Recently, Ozturk et $a .^{5)}$ used the similar technique as the present study to measure the equilibrium titanium and nitrogen contents in $\mathrm{Fe}-\mathrm{Cr}$ melts in the presence of pure solid 
TiN under $1 \mathrm{~atm}$ nitrogen pressure. They reported the value of $e_{\mathrm{Ti}}^{\mathrm{Cr}}$ as 0.024 at $1873 \mathrm{~K}$ from a plot of $\log f_{\mathrm{Ti}} v s$. Cr contents up to 18 mass $\%$ in iron. In their calculation, however, the strong interaction between nitrogen and titanium $\left(e_{\mathrm{Ti}}^{\mathrm{N}}=\right.$ -2.041 at $1873 \mathrm{~K}$ ) was not considered at high nitrogen contents in $\mathrm{Fe}-\mathrm{Cr}$ melts under $1 \mathrm{~atm}$ nitrogen pressure. When their experimental data were reexamined using the relation of Eq. (3), $e_{\mathrm{Ti}}^{\mathrm{Cr}}$ and $r_{\mathrm{Ti}}^{\mathrm{Cr}}$ values can be obtained as 0.0312 and 0.00032 , respectively, at $1873 \mathrm{~K}$.

The validity of $e_{\mathrm{Ti}}^{\mathrm{Cr}}$ values determined in the present study will be discussed in the later section.

\subsection{Solubility of Nitrogen}

The dissolution of nitrogen in liquid iron alloys can be written as

$$
\begin{aligned}
& \frac{1}{2} \mathrm{~N}_{2}(\mathrm{~g})=\underline{\mathrm{N}} \ldots \ldots . . . . . \\
& \Delta G_{4}^{\circ}= 3598+23.89 T \quad \mathrm{~J}^{8)} \\
& K_{4}=\frac{f_{\mathrm{N}}[\% \mathrm{~N}]}{P_{\mathrm{N}_{2}}^{1 / 2}}
\end{aligned}
$$

where $K_{4}$ is the equilibrium constant for Reaction (4), and $f_{\mathrm{N}}$ is the activity coefficient of nitrogen in 1 mass $\%$ standard state in liquid iron.

Using the similar relations as Eqs. (2) and (3), the equilibrium constant $K_{4}$ can be rewritten as

$$
\begin{aligned}
\log K_{4}= & \log f_{\mathrm{N}}+\log [\% \mathrm{~N}]-\frac{1}{2} \log P_{\mathrm{N}_{2}} \\
= & e_{\mathrm{N}}^{\mathrm{Cr}}[\% \mathrm{Cr}]+r_{\mathrm{N}}^{\mathrm{Cr}}[\% \mathrm{Cr}]^{2}+e_{\mathrm{N}}^{\mathrm{Ti}}[\% \mathrm{Ti}]+e_{\mathrm{N}}^{\mathrm{N}}[\% \mathrm{~N}] \\
& +e_{\mathrm{N}}^{\mathrm{O}}[\% \mathrm{O}]+\log [\% \mathrm{~N}]-\frac{1}{2} \log P_{\mathrm{N}_{2}} \ldots \ldots \ldots \ldots . . .
\end{aligned}
$$

then

$$
\begin{aligned}
& \log f_{\mathrm{N}}^{\mathrm{Cr}}=e_{\mathrm{N}}^{\mathrm{Cr}}[\% \mathrm{Cr}]+r_{\mathrm{N}}^{\mathrm{Cr}}[\% \mathrm{Cr}]^{2} \\
& =\log K_{4}-e_{\mathrm{N}}^{\mathrm{Ti}}[\% \mathrm{Ti}]-e_{\mathrm{N}}^{\mathrm{N}}[\% \mathrm{~N}]-e_{\mathrm{N}}^{\mathrm{O}}[\% \mathrm{O}] \\
& -\log [\% \mathrm{~N}]+\frac{1}{2} \log P_{\mathrm{N}_{2}}
\end{aligned}
$$

where $f_{\mathrm{N}}^{\mathrm{Cr}}$ is the interaction coefficient of $\mathrm{Cr}$ on $\mathrm{N}$, and $e_{\mathrm{N}}^{\mathrm{Cr}}$ and $r_{\mathrm{N}}^{\mathrm{Cr}}$ are the first and second order interaction parameters of $\mathrm{Cr}$ on $\mathrm{N}$ in liquid iron.

Therefore, the values of $e_{\mathrm{N}}^{\mathrm{Cr}}$ and $r_{\mathrm{N}}^{\mathrm{Cr}}$ in Eq. (6) can be determined from the experimental results and available thermodynamic parameters shown in Table 2., ${ }^{2,72)}$ Figure 3 shows the values of $\log f_{\mathrm{N}}^{\mathrm{Cr}}$ plotted $v s$. percent chromium in the alloys using the relation expressed by Eq. (6). The effect of oxygen content in the melt on the $f_{\mathrm{N}}^{\mathrm{Cr}}$ value was negligible at the oxygen level obtained in the present study. The first order interaction parameter, $e_{\mathrm{N}}^{\mathrm{Cr}}$ can be determined as -0.045 at $1873 \mathrm{~K}$ by a linear regression analysis of data. This value is in excellent agreement with the values of -0.045 obtained by Pehlke and Elliott ${ }^{13)}$ and -0.046 obtained by Wada et al. ${ }^{3)}$ at $1873 \mathrm{~K}$. The second order parameter can be considered as zero. The $e_{\mathrm{N}}^{\mathrm{Cr}}$ values at other temperatures are also shown in Fig. 3. The temperature dependence of $e_{\mathrm{N}}^{\mathrm{Cr}}$ value is shown in Fig. 4, and it can be expressed as $-850 / T+0.409$. The interaction parameters determined in the present study are compared with previous

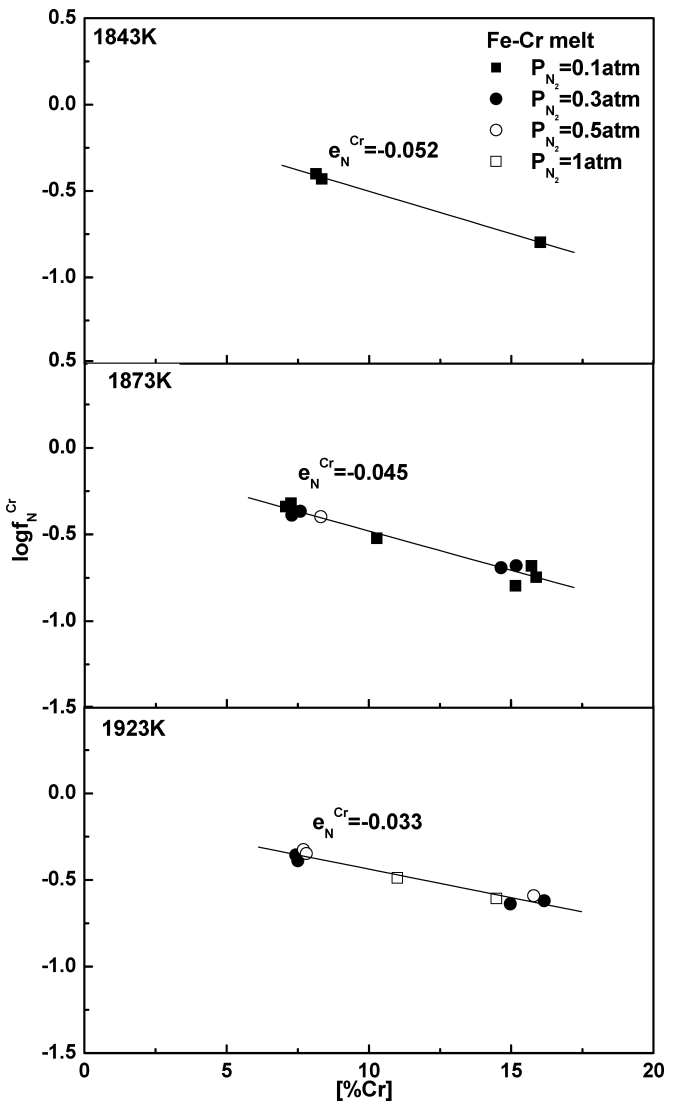

Fig. 3. Relations between $\log f_{\mathrm{N}}^{\mathrm{Cr}}$ and $[\% \mathrm{Cr}]$ in $\mathrm{Fe}-\mathrm{Cr}-\mathrm{Ti}-\mathrm{N}$ melts.

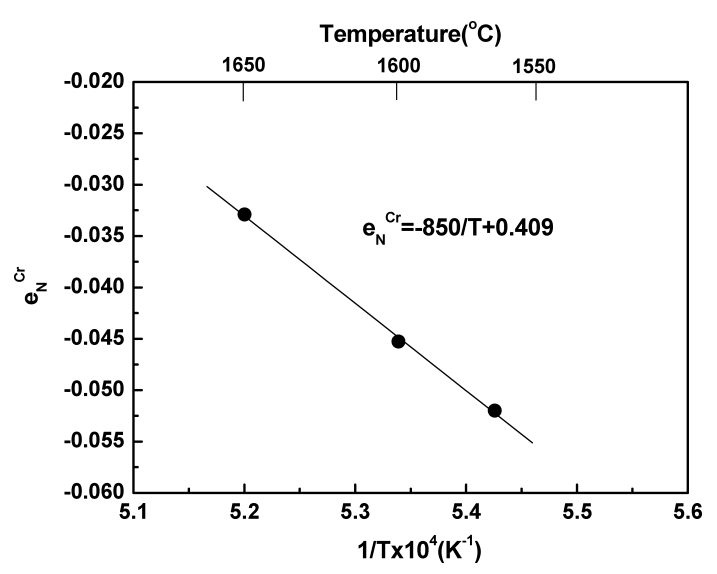

Fig. 4. Temperature dependence of $e_{\mathrm{N}}^{\mathrm{Cr}}$ in molten Fe.

results $^{2,3,13)}$ in Table 3.

\subsection{Thermodynamics of TiN Formation}

The reaction equilibrium for the formation of TiN in liquid iron can be written as

$$
\begin{gathered}
\operatorname{TiN}(\mathrm{s})=\underline{\mathrm{Ti}}+\underline{\mathrm{N}} \ldots \ldots \ldots \ldots . . . . . . . . \\
\Delta G_{7}^{\circ}=379000-149 T \quad \mathrm{~J}^{7)} \\
K_{7}=\frac{h_{\mathrm{Ti}} h_{\mathrm{N}}}{a_{\mathrm{TiN}}}=f_{\mathrm{Ti}} f_{\mathrm{N}}[\% \mathrm{Ti}][\% \mathrm{~N}]
\end{gathered}
$$

The equilibrium constant $K_{7}$ can be rewritten as 


$$
\begin{aligned}
\log K_{7} & =\log f_{\mathrm{Ti}}+\log f_{\mathrm{N}}+\log [\% \mathrm{Ti}][\% \mathrm{~N}] \\
& =\sum_{i} e_{\mathrm{Ti}}^{i}[\% i]+\sum_{i} e_{\mathrm{N}}^{i}[\% i]+\log [\% \mathrm{Ti}][\% \mathrm{~N}] \ldots
\end{aligned}
$$

Therefore, using relevant thermodynamic parameters, it is possible to construct the TiN stability diagram for a commercial grade type 409 stainless steel (Fe-11mass\%Cr0.4 mass Si\%-Ti-N) as shown in Fig. 5. The solid line was calculated using Eq. (8) and the values of $e_{\mathrm{Ti}}^{\mathrm{Cr}}$ and $e_{\mathrm{N}}^{\mathrm{Cr}}$ determined in the present study and available thermodynamic data given in Table 2 .

In order to check the validity of the TiN stability diagram, an experiment was carried out to observe under what condition titanium nitride forms at controlled titanium and nitrogen contents in the melt. Three 409 stainless steel

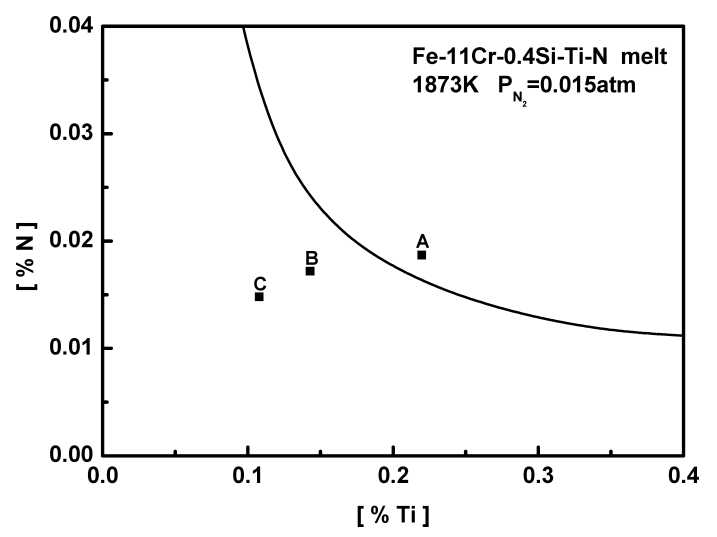

Fig. 5. Stability diagram of $\mathrm{TiN}$ for $\mathrm{Fe}-11 \% \mathrm{Cr}-0.4 \% \mathrm{Si}-\mathrm{Ti}-\mathrm{N}$ melt at $1873 \mathrm{~K}$ samples containing different titanium contents (0.150.3 mass $\% \mathrm{Ti}$ ) were equilibrated in an $\mathrm{Ar}-1.5 \% \mathrm{~N}_{2}$ mixture gas atmosphere at $1873 \mathrm{~K}$ for $12 \mathrm{~h}$. The equilibrium nitrogen solubility in the sample melts under this condition was estimated as $0.02-0.025$ mass \% depending on the initial titanium content from Eqs. (4) and (5). Titanium nitride pellet was not added in this experiment.

After the equilibration, the samples were water quenched and analyzed for soluble titanium and nitrogen contents (points A, B and C in Fig. 5). According to the stability diagram for TiN at $1873 \mathrm{~K}$, the melt with titanium and nitrogen contents of point $\mathrm{A}$ would form TiN inclusions, whereas $\mathrm{B}$ and $\mathrm{C}$ would not form TiN inclusions. Inclusion analysis by EPMA for metal samples identified inclusions in the sample A as TiN as shown in Fig. 6. The size of these primary TiN inclusions was in the range of $2-3 \mu \mathrm{m}$. TiN inclusions were not observed in samples B and C.

Another experiment was carried out to see the effect of lowering melt temperature on the formation of secondary TiN inclusions from $\mathrm{Fe}-11$ mass $\% \mathrm{Cr}-\mathrm{Ti}-\mathrm{N}$ melt. Three $\mathrm{Fe}-11 \mathrm{mass} \% \mathrm{Cr}$ samples with titanium contents of $0.1-$ $0.2 \mathrm{mass} \%$ were equilibrated in the same $\mathrm{Ar}-1.5 \% \mathrm{~N}_{2}$ atmosphere at $1873 \mathrm{~K}$ for $12 \mathrm{~h}$. The $\mathrm{Ar}-\mathrm{N}_{2}$ gas mixture was switched to an $\mathrm{Ar}-3 \% \mathrm{H}_{2}$ gas. After holding the sample melts for another $2 \mathrm{~h}$ at $1873 \mathrm{~K}$, the crucibles were slowly raised from the hot zone to a lower temperature zone where the temperature was predetermined as $1800 \mathrm{~K}$ that is a few degrees higher than the melting point of $\mathrm{Fe}-11 \mathrm{mass} \% \mathrm{Cr}$ alloy $(\sim 1793 \mathrm{~K})$. The sample melts were held at $1800 \mathrm{~K}$ for an hour, and then the crucibles were pulled out and water quenched.

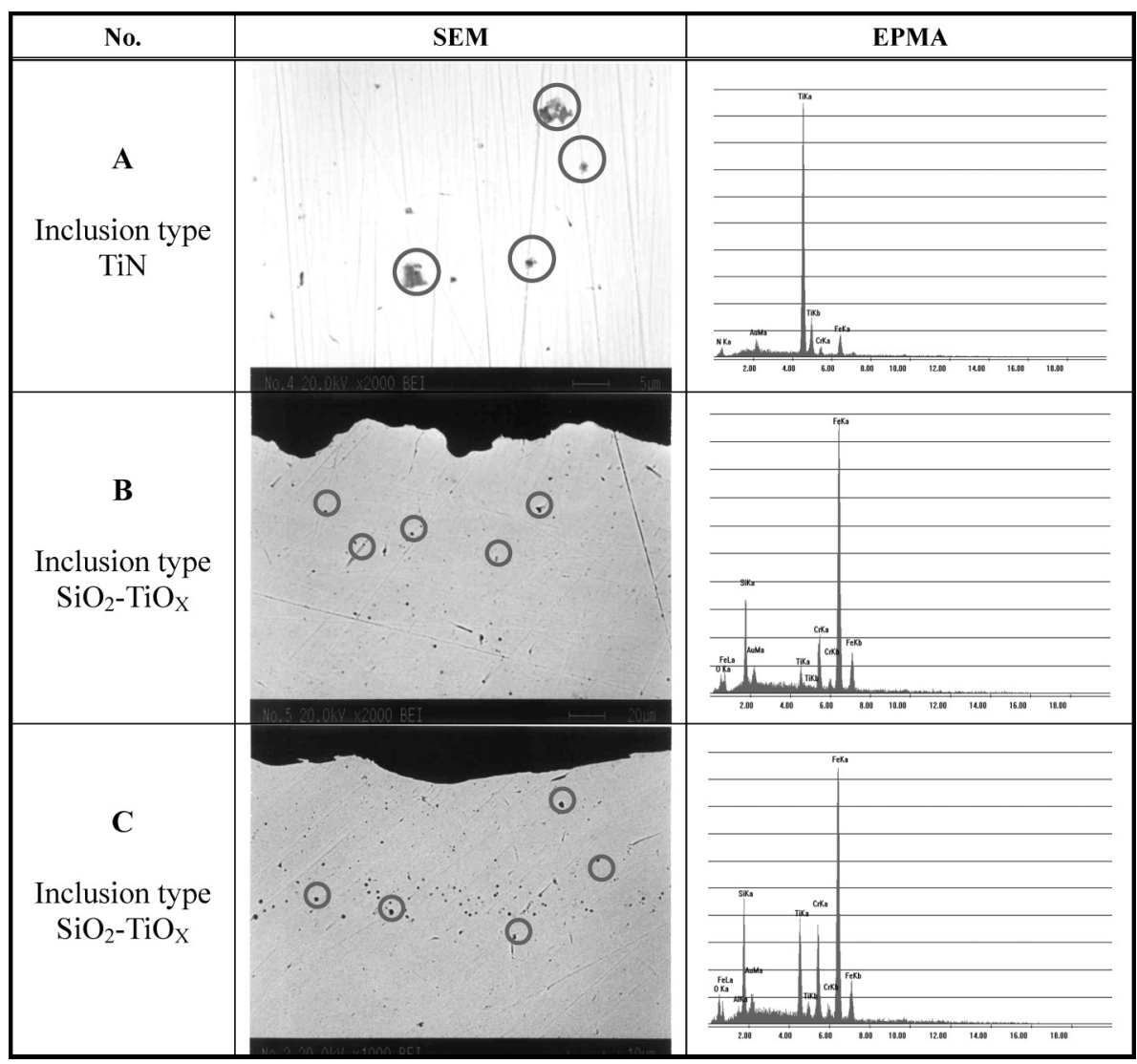

Fig. 6. SEM images and EPMA data of inclusions in $\mathrm{Fe}-11 \% \mathrm{Cr}-0.4 \% \mathrm{Si}-\mathrm{Ti}-\mathrm{N}$ melt. 
The soluble titanium and nitrogen contents analyzed in metal samples are shown as points D, E and F in Fig. 7. The stability diagrams for $\mathrm{TiN}$ in a $\mathrm{Fe}-11$ mass $\% \mathrm{Cr}$ alloy at $1873 \mathrm{~K}$ and $1800 \mathrm{~K}$ are also shown in the figure. According to the stability diagram, all sample melts would not form TiN inclusions at $1873 \mathrm{~K}$. However, as the melt temperature decreases to $1800 \mathrm{~K}$, it can be expected that TiN precipitate as secondary inclusions for samples D and E. Inclusion analysis by EPMA for these samples could not identify any primary TiN inclusions. However, as shown in Fig. 8, TEM-EDS analysis on sample D and E identified fine secondary TiN inclusions of $0.3-0.5 \mu \mathrm{m}$ precipitated from the melts on cooling. TiN inclusions were not observed in sample $\mathrm{F}$.

The above results verify that thermodynamic parameters of chromium on titanium and nitrogen determined in the present study are valid for the thermodynamic calculation of TiN formation in $\mathrm{Fe}-\mathrm{Cr}-\mathrm{Ti}-\mathrm{N}$ system as a function of temperature.

\section{Conclusions}

Thermodynamics of TiN formation in $\mathrm{Fe}-\mathrm{Cr}$ melts was studied by measuring the equilibrium titanium and nitrogen

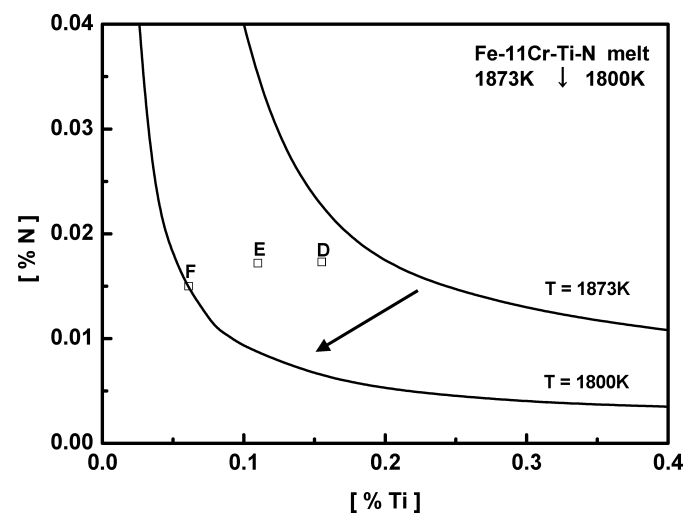

Fig. 7. Stability diagram of $\mathrm{TiN}$ for $\mathrm{Fe}-11 \% \mathrm{Cr}-\mathrm{Ti}-\mathrm{N}$ melt. contents of the melt in the presence of pure solid TiN under various nitrogen partial pressures. The activity coefficients of titanium and nitrogen, and the interaction parameters of chromium on titanium and nitrogen were determined as a function of temperature. Chromium increases the solubility product of TiN in $\mathrm{Fe}-\mathrm{Cr}$ melt, and the effect of chromium on the solubility product of TiN is primarily due to the large effect of chromium on the solubility of nitrogen in the iron melt. Thermodynamic calculations for TiN formation in $\mathrm{Fe}-\mathrm{Cr}$ melts using the parameters determined in the present study were in excellent agreement with the experimental results of observing the formation of primary TiN inclusions in the melt at $1873 \mathrm{~K}$, and the formation of secondary TiN inclusions on cooling.

\section{Acknowledgments}

The authors wish to thank Dr. Joo-Hyun Park, the Stainless Steel Research Group, Technical Research Lab., POSCO, for help with the inclusion analysis by EPMA, and Mr. Gil-Yeol Ryu, RIST, Pohang for help with the inclusion analysis by TEM-EDS. The present work was financially supported by POSCO. (Grant No.: 2003Z02).

\section{REFERENCES}

1) H. Fujimura, S. Tsuge, Y. Komizo and T. Nishizawa: Tetsu-toHagané, 87 (2001), 707.

2) G. K. Sigworth and J. F. Elliott: Met. Sci., 8 (1974), 298.

3) H. Wada and R. D. Pehlke: Metall. Trans. B, 8B (1977), 443.

4) G. Yuanchang and W. Changzhen: Metall. Trans. B, 21B (1990), 543.

5) B. Ozturk, R. Matway and R. J. Fruehan: Metall. Trans. B, 26B (1995), 563.

6) J. J. Pak, J. T. Yoo, Y. S. Jeong, S. J. Tae, S. M. Seo, D. S. Kim and Y. D. Lee: ISIJ Int., 45 (2005), 23.

7) Z. Morita and K. Kunisada: Tetsu-to-Hagané, 63 (1977), 1663.

8) E. T. Turkdogan: Physical Chemistry of High Temperature Technology, Academic Press, New York, (1980), 81.

9) D. Janke and W. A. Fischer: Arch. Eisenhüttenwes., 47 (1976), 195.

10) M. Kishi, R. Inoue and H. Suito: ISIJ Int., 34 (1994), 859.

11) C. H. P. Lupis and J. F. Elliott: Acta Metall., 14 (1960), 529.

12) A. Sieverts and G. Zapf: Z. Phys. Chem. A, 172 (1935), 341.

13) R. D. Pehlke and J. F. Elliott: Trans. Metall. Soc., 218 (1960), 1088.

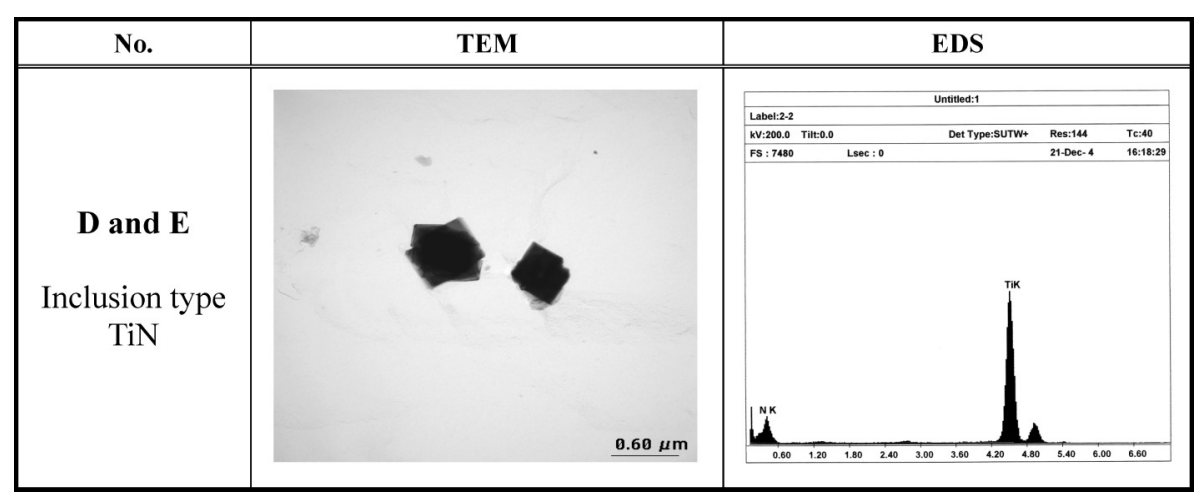

Fig. 8. TEM image and EDS data of inclusions in $\mathrm{Fe}-11 \% \mathrm{Cr}-\mathrm{Ti}-\mathrm{N}$ melt. 